\title{
Pacific Harbor Seal (Phoca vitulina richardii). Haul Out Impact on the Rocky Midtidal Zone
}

\author{
J. Boal \\ Hopkins Marine Station of Stanford University, Pacific Grove, California 93940, USA
}

\begin{abstract}
A study of haul out and adjacent non-haul out rocks of the Pacific harbor seal Phoca vitulina richardii (Gray), Rice, on the Monterey Peninsula of California (USA), revealed significant differences in algal morphology and per cent composition, and in numbers of animals present. It is suggested that the mechanical and chemical impact imposed by the seals on the haul out sites are responsible for these differences.
\end{abstract}

\section{INTRODUCTION}

Previous studies on the environmental impact of the common harbor seal Phoca vitulina (Linnaeus) have focused on effects related to the fishing industry (Bonnot, 1932; Caldwell, 1972; Newby, 1978; Boulva, 1979). A review of the literature revealed no work on impact regarding any other aspect of the marine community. Paulbitsky (1975) reports that 50-200,000 seals are hauling out at regular sites of different kinds around the world. The study reported here was undertaken to determine if hauling out is affecting the rocky intertidal community. The report details the differences between the size and distribution of organisms within quadrates on exisient haul out rocks and those on nearby control rocks picked to be as similar as possible to the haul out rocks. Since seals were neither excluded from an established haul out site, nor made to haul out in a new area, direct causality could not be demonstrated.

\section{MATERIALS AND METHODS}

Research was done between April and June and between August and October of 1979, on the Monterey Peninsula in California, USA. Three paired groups of haul out and control rocks were chosen, two paired groups at Hopkins Marine Station of Stanford University, and one paired group at Stillwater Cove, Pebble Beach. Each group of rocks was bordered by water at least $1 \mathrm{~m}$ deep at low tide. Rocks examined ranged in height from 0 to $2 \mathrm{~m}$ above mean lower low water.
The primary study area consisted of Seal Island (SI), a small rocky island about $50 \mathrm{~m}$ off Hopkins Marine Station shore where about 30 seals have been hauling out for over 5 years (Abbott and Baldridge, personal communication). The Island is also inhabited by birds, primarily seagulls and cormorants. It was arbitrarily divided into two sampling areas. Six clusters of control rocks along the nearby shore were chosen to be as much like the island as possible (Table 1).

A second sample area of haul out (HO) and non-haul out (NHO) rocks was located at Bird Island (BI), a rocky island just north of Seal Island. Part of this island was the occasional haul out site of about 6 seals. The control area for this haul out site was a group of rocks that appeared identical in all ways except that they were closer to the mainland and had less direct access to the open bay water.

The third comparison group of rocks was located at Stillwater Cove (SWC) where approximately 8 seals have hauled out regularly. Haul out rocks were those rocks not directly connected to the shore, plus a pair of large, sloping rocks jutting out into the cove. The nonhaul out control sites chosen consisted of rocks that seemed different only in that they lay closer to the main shore.

Individual rocks within these areas were chosen by random number coordinate systems. Where the shore was more or less linear, the first random number coordinate determined the distance along the shore from some arbitrary point, and the second random number coordinate determined the distance in from the water, on an axis perpendicular to the shoreline. Where rocks lay in clusters, a different system was 


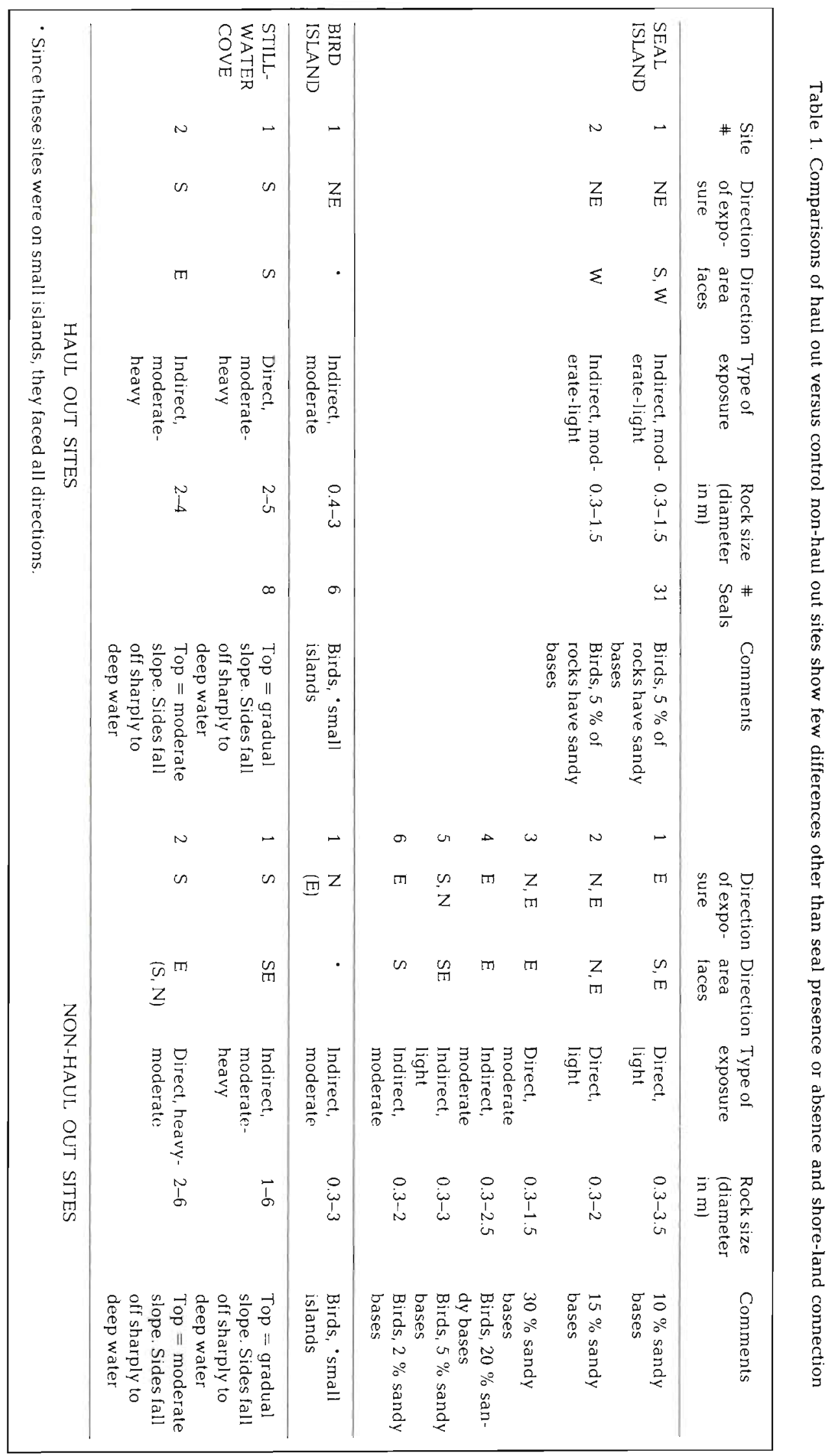


used. An arbitrary point at approximately the center of the cluster was chosen. Then, the first random number determined the angle from some arbitrary fixed point, and the second number, the distance from the point in that angular direction.

For the algal studies, $40 \times 40 \mathrm{~cm}$ quadrates were used on the rock tops, and four $20 \times 20 \mathrm{~cm}$ quadrates were used on the rock sides. Stillwater Cove is an exception to this; $40 \times 20 \mathrm{~cm}$ quadrates were used for the rock sides, due to the very large rock sizes. Quadrates were subdivided into $4 \times 4 \mathrm{~cm}$ squares, and the number of small squares a given type of algae occupied was converted to a percent cover of the total sampling area. Exceptions to this procedure are noted in the text.

For animal studies, the $40 \times 40 \mathrm{~cm}$ rock top quadrates were also used. Animals on rock sides, however, were counted within a band of $5 \mathrm{~cm}$ on either side of four $50 \mathrm{~cm}$ transect lines running down the rock sides.

Fronds and holdfasts sampled were chosen by random number coordinates within the quadrates, and small animals were counted under a dissecting scope from $6.5 \mathrm{~cm}^{2}$ holdfast samples.

\section{RESULTS}

\section{Effects on Algae}

Seventeen species of algae were studied for cover differences. Three were found to differ significantly between haul out and non-haul out sites.

Per cent cover of Gigartina canaliculata (Harvey) was found to be significantly greater on all areas of haul out rocks (Fig. 1). At Bird Island, the percent cover

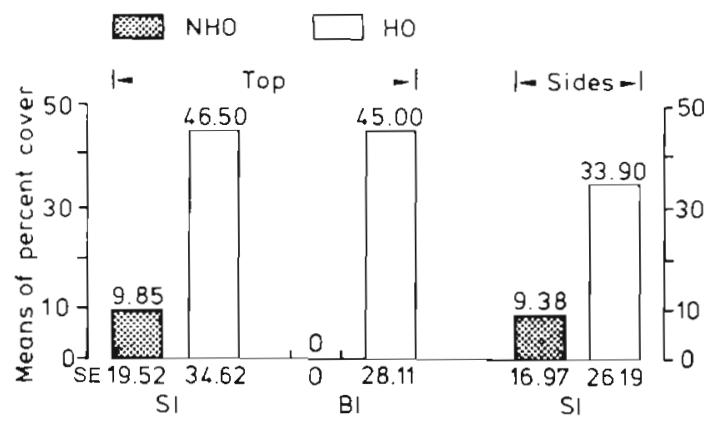

Fig. 1. Gigartina canaliculata. Percent cover differences are significant (Student's $t$-test). NHO: Non-haul out sites; $\mathrm{HO}$ : haul out sites. SI (Seal Island): $n_{\mathrm{NHO}}=65, \quad n_{\mathrm{HO}}=26$, $t_{\mathrm{YOP}}=6.39, t_{\mathrm{SIDES}}=3.01$. BI (Bird Island): $n_{\mathrm{NHO}}=50$, $n_{\mathrm{HO}}=60, t=11.31$. SE: standard error

was determined by random point identifications rather than simple percent cover, and was significantly different at haul out and non-haul out sites, with $p<<0.001$.
There was a significantly higher ( $p<<0.001)$ percent cover of Ulva californica on the tops of the haul out rocks at Stillwater Cove (Fig. 2). While the percent cover did not differ significantly elsewhere, there was an overall greater occurrence of $U$. californica on the tops of haul out rocks at Seal Island than the non-haul out rocks $(p<0.005)$ and also along the rock sides at Stillwater Cove $(p<0.05)(R \times C$ contingency test; Fig. 2).

A reduction in cover of Cladophora columbiana (Collins) occurred where seals hauled out (Fig. 3). Per cent cover was significantly less at Stillwater Cove both for the rock tops $(p<0.001)$ and the rock sides $(p$

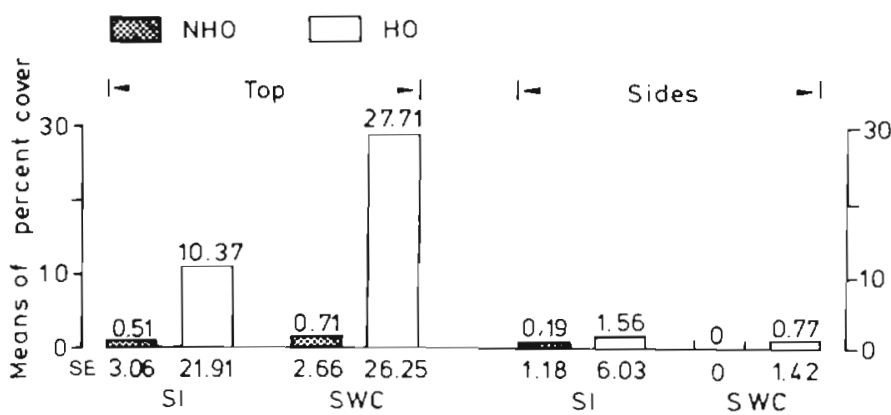

Fig. 2. Ulva californica. Percent cover differences on rock tops of Stillwater Cove. Student's $t$-test. Elsewhere, $t$ was insignificant. $R \times C$ contingency tests were significant on rock tops of Seal Island and rock sides of Stillwater Cove. Seal Island rock sides $G$ value was insignificant. SI: $n_{\mathrm{NHO}}=75$, $n_{\mathrm{HO}}=30, G_{\mathrm{TOP}}=12.788, G_{\mathrm{SDES}}=0.848$. SWC (Stillwater Cove): top, $n_{\mathrm{NHO}}=n_{\mathrm{HO}}=17, \quad t=4.22 ; \quad$ sides, $n_{\mathrm{NHO}}=n_{\mathrm{HO}}=12, G=4.588$

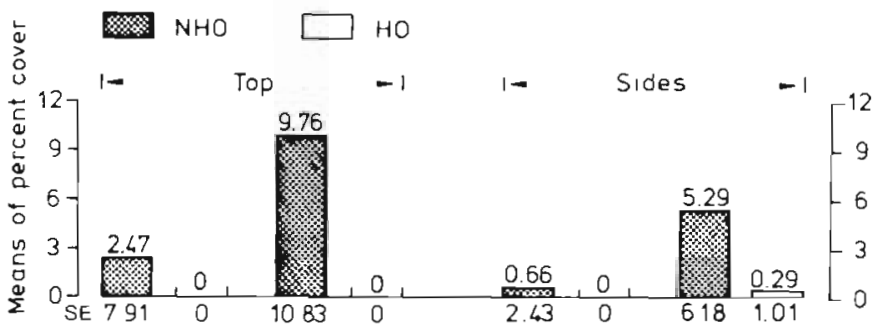

Fig. 3. Cladophora columbiana. Significant percent cover differences at Stillwater Cove only. Student's $t$-test. Significant differences using $R \times C$ contingency tests were found at Seal Island. SWC: top, $n_{\mathrm{NHO}}=n_{\mathrm{HO}}=17, t=3.72$; sides, $n_{\mathrm{NHO}}=n_{\mathrm{HO}}=12, \quad t=2.77 . \quad$ SI: $\quad n_{\mathrm{NHO}}=75, \quad n_{\mathrm{HO}}=30$, $G_{\mathrm{TOP}}=11.066, G_{\mathrm{SIDES}}=7.908$

$<0.02)$ (Student's $t$-test). And there was a reduction in overall occurrence on the haul out rocks compared to the non-haul out rocks of Seal Island ( $p<0.005$ for top and for sides, using $R \times C$ contingency test).

Frond heights of algae in haul out and non-haul out areas were compared as an index to morphological differences. Significant differences were found in both Gigartina canaliculata and Rhodoglossum affine (Har- 
californica is able to compete well under this stress, and hence is more often found on haul out than nonhaul out rock tops.

Chemical/environmental stresses include fecal and urinary fertilization (Johnson, 1979), warmth, humidity, and shade, all provided by the seals' bodies at what are normally the rocks' most exposed times of day. These factors may be having a strong effect on the microscopic biota present, which might explain the high numbers of grazing Barleeia haliotiphila, Lasea cistula, and Tricolia pulloides found. It is interesting to note that areas of Bird Island heavily fertilized by guano but not visited by seals did not show any of these haul out site differences in plants or animals.

Both Gigartina canaliculta and Rhodoglossum affine plants were found to be shorter on haul out rock tops than might be expected from heights elsewhere. This could be due to either the mechanical or the chemical/ environmental stresses. However, since $G$. canaliculata is taller on the rock sides, it may be that it is benefiting from the fertilizing, but that one of the other factors is preventing tall growth on top. $R$. affine was not taller on the rock sides, nor did it show a greater per cent cover on the haul out rocks, as did G. canaliculata. Apparently, whether it is the fertilizing or some other factor that is benefiting $G$. canaliculata, $R$. affine is not being affected by it. More work is needed to sort out exact cause-effect relationships.

If the differences in organisms found in this study between haul out and non-haul out sites hold true throughout the harbor seal distribution range, their presence may be affecting the local distribution of plants and animals everywhere, and hence are a further factor to take into account when studying the intertidal zone. It seems desirable to critically examine whether other hauling out marine mammals are affecting the organisms in the area of their haul out, as well.

Acknowledgements. I would particularly like to thank Robin Burnett for his time, suggestions, and help, which have been invaluable. I also want to thank Alan Baldridge and Judson Vandevere, who were of great help with their familiarity with the local marine mammal populations. Also appreciated are John and Nancy Love, for granting me access to the Stillwater Cove harbor seal haul out site, and Julie Packard for help in algal identifications.

\section{LITERATURE CITED}

Bonnot, P. (1932). Food habits of the Pacific harbor seal (Phoca richardii). Calif. Fish \& Game 18: 98

Boulva, H., McLaren, I. A. (1979). Biology of the Harbor Seal, Phoca vitulina, in eastern Canada. Bull. Fish Res. Bd Can. 200: 24

Caldwell, M. C., Caldwell, D. K. (1972). Behavior of marine mammals. In: Ridgeway, S. H. (ed.) Mammals of the sea: biology and medicine. Charles $\mathrm{C}$. Thomas, Springfield, Illinois, pp. 440-465

Johnson, D., Siperstein, L. (1979). Observations on the behaviour of the harbor seal (Phoca vitulina richardii) at Hopkins Marine Station. Biology $160 \mathrm{H}$ paper on file at the Hopkins Marine Station Library

Newby, T. C. (1978). Pacific harbor seal. In: Haley, D. (ed.) Marine mammals of eastern North Pacific and Arctic waters. Pacific Search Press, Seattle, pp. 184-191

Paulbitsky, P. A. (1975). The seals of Strawberry Spit. Pac. Discovery 28: $12-15$ 